\title{
Prey-dependent foraging tactics and prey profitability in a marine mammal
}

\author{
W. D. Bowen ${ }^{1, *}$, D. Tully' ${ }^{2}$, D. J. Boness ${ }^{3}$, B. M. Bulheier ${ }^{4}$, G. J. Marshall ${ }^{4}$ \\ ${ }^{1}$ Marine Fish Division, Bedford Institute of Oceanography,Department of fisheries and Oceans, Dartmouth, \\ Nova Scotia B2Y 4A2, Canada \\ ${ }^{2}$ Department of Biology, Dalhousie University, Halifax, Nova Scotia B3H 4J1, Canada \\ ${ }^{3}$ Department of Zoological Research, Smithsonian Institution, Washington, DC 20008, USA \\ ${ }^{4}$ National Geographic Television, Washington, DC 20036, USA
}

\begin{abstract}
Predators face decisions about which prey to include in their diet in order to maximize fitness. The foraging tactics used to capture prey and the resulting profitability of prey influence these decisions. We present the first evidence of prey-dependent foraging tactics and prey profitability in a free-ranging pinniped. We studied 39 adult male harbour seals Phoca vitulina at Sable Island, Nova Scotia using an animal-borne video system. Each male wore the camera system for $3 \mathrm{~d}$ during which 10 min video samples were recorded every 45 min from 06:00 h, resulting in approximately $3 \mathrm{~h}$ of videotape per male and a total of 1094 capture attempts of identified prey. Males foraged mainly on sand lance Ammodytes dubius and flounders (Pleuronectids), but salmonid and gadoid fishes were occasionally pursued. Foraging tactics differed among and within prey types based on differences in prey behaviour. Sand lance was both a cryptic prey, when in the bottom substrate, and a conspicuous schooling prey. Seal swimming speed, handling time and capture success differed between cryptic and conspicuous sand lance. The highest capture success and handling time was recorded for flounders. Estimated profitability, i.e. net energy intake per unit time, also differed with prey type and prey size. Our results suggest that diet selection may have important implications on the foraging energetics of pinnipeds.
\end{abstract}

KEY WORDS: Foraging $\cdot$ Tactics $\cdot$ Prey profitability $\cdot$ Pinniped $\cdot$ Arbour seal

\section{INTRODUCTION}

The tactics used by predators to capture prey and the energetic consequences of these behaviours can influence which foods are eaten (Emlen 1966, Schoener 1971). The effect of prey size, energy content, and behaviour on foraging tactics has been investigated in many aquatic and terrestrial species (Stephens \& Krebs 1986, Sunquist \& Sunquist 1989, Kruuk 1993, Kvitek et al. 1993, Scheel 1993, Hart 1997). However, apart from theoretical studies (e.g. Kramer 1988, Houston \& Carbonne 1992, Thompson et al. 1993), relatively

*Email: bowend@mar.dfo-mpo.gc.ca little is known about how diving and prey characteristics affect the foraging tactics of pinnipeds and seabirds (Boyd 1996, Ropert-Coudert et al. 2002). The reasons for this are not difficult to appreciate, as most pinnipeds forage at considerable water depths, often in remote locations. Thus, studies of pinniped foraging behaviour have emphasized the description of diet and its relation to prey abundance, using indirect methods, such as stomach content and fecal analyses (Pierce \& Boyle 1991, Bowen \& Siniff 1999). For some species, such as the Antarctic fur seal Arctocephalus gazella, the association between diving and foraging seems quite clear due to the specialized diet of krill Euphausia superba and the known distribution of this single prey (Croxall et al. 1985). However, even with the 
Antarctic fur seal, we do not know how individuals capture prey. Thus, for most pinniped species the methods used to study foraging and diet fall short of providing information on foraging tactics and how these tactics vary with prey characteristics.

Pinnipeds are apex predators that likely have important top-down effects on marine ecosystems (Bowen 1997, Boveng et al. 1998). Developing an understanding of the prey-specific foraging tactics and the relative profitability of different prey will be needed if we are to better understand pinniped-prey interactions in marine ecosystems. Such interactions are of practical importance in the management of harvested fish and invertebrates and in the conservation of threatened pinniped species (Mohn \& Bowen 1996, Merrick \& Loughlin 1997, Parrish et al. 2000).

The harbour seal Phoca vitulina is a member of the family Phocidae, which inhabits temperate coastal waters throughout the northern hemisphere (King 1983). In eastern Canada, they feed on a variety of benthic and pelagic prey (Bowen \& Harrison 1994) and as a result during foraging must overcome a range of anti-predator behaviours by their prey. Prey such as flatfishes are cryptically coloured and often hidden within sandy bottoms, whereas schooling species such as herring and capelin present quite different problems to predators. These different anti-predator behaviours suggest that we might expect harbour seals to vary capture tactics in relation to prey behaviour, as seen in other predators (Schaller 1972, Diaz \& Carrascal 1993, Kruuk 1993, Kvitek et al. 1993, Somers 2000). The tactics used by predators to capture prey may also affect the profitability of prey, defined as the quotient of net energy intake (e) divided by handling time (h) (Schoener 1971, Pulliam 1974). Handling time is the total time taken for a predator to pursue, capture and consume a prey item. An understanding of prey profitability is important as foraging models predict that foods are included in the diet based partly on profitability (Schoener 1971, Stephens \& Krebs 1986).

The recent development of animal-borne video systems permits the observation of foraging behaviour in free-ranging marine vertebrates (Marshall 1998, Davis et al. 1999). Thus, it is now possible to examine the components of foraging tactics used by marine carnivores to capture prey. Harbour seals are known to consume both cryptic and non-cryptic prey near Sable Island (W. D. Bowen unpubl. data) and thus we expected seals to adjust their foraging tactics to capture these different types of prey. Our objectives in this study were to examine the influence of prey type on foraging tactics of adult male harbour seals and to provide initial estimates of prey profitability.

\section{MATERIALS AND METHODS}

Study area and the video system. The study was conducted on Sable Island, Canada $\left(43^{\circ} 55^{\prime} \mathrm{N}, 60^{\circ} 00^{\prime} \mathrm{W}\right)$ during the 1995 to 1997 harbour seal breeding seasons (i.e. May-June of each year). Sable Island is a vegetated sandbar approximately $42 \mathrm{~km}$ long and $1.5 \mathrm{~km}$ wide, located $288 \mathrm{~km}$ south-east of Halifax, Nova Scotia. At this time of year, adult male harbour seals can be easily captured and recaptured, as they reliably return to the island after brief foraging trips (Walker \& Bowen 1993, Coltman et al. 1997). This made the shortterm deployment and retrieval of the videotape system possible. Adult males were captured with hand-held nets and weighed to the nearest $0.5 \mathrm{~kg}$ with a Salter spring balance. Seals were then sedated with approximately $0.2 \mathrm{mg} \mathrm{kg}^{-1}$ body mass of diazepam to permit attachment of the Crittercam video-imaging and datalogging system. Standard dorsal length (McLaren 1993) was taken after the animal was relaxed under the influence of the sedative.

The National Geographic's Crittercam is an integrated Hi8 video camcorder and programmable datalogging system contained within a waterproof housing (Fig. 1). The housing is a cylindrical aluminium tube $(\sim 10 \times 25 \mathrm{~cm})$ with a conical flotation tail-section. The system was positively buoyant and weighed approximately $2 \mathrm{~kg}$ in air. In addition to filming underwater behaviour from the animal's perspective, the system recorded water temperature and depth every $7 \mathrm{~s}$ for the duration of the deployment. Some deployments also included an externally mounted hydrophone to collect acoustic data while recording video images. A saltwater switch prevented the camera from recording when the animal was hauled out on the beach. A more detailed description of the technical specifications of Crittercam is given in Marshall (1998). The camcorder was programmed to sample continuously for $10 \mathrm{~min}$ every 45 min beginning at 05:30 or 06:00 h and ending between 14:00 and 15:00 h local time. This sampling period was based on a compromise between the length of the videotape $(3 \mathrm{~h})$ and the activity pattern of males (i.e. males tended to haul out on land during the afternoon; Walker \& Bowen 1993). Each 10 min period of continuous videotape or portion thereof was termed a video-sampling unit (VSU). The camera had an angular field of view of $88^{\circ}$ by $68^{\circ}$ and we estimated that in the water conditions around Sable Island, objects could be clearly seen about $10 \mathrm{~m}$ ahead of the camera.

Crittercam was attached to a light microsphere, epoxy mount with stainless steel hose clamps. The combined mass of the video system and epoxy mount averaged about $1.8 \%$ of body mass of the male harbour seals used in the study. The cross-sectional area of the Crittercam was about $4.5 \%$ of that of our study ani- 


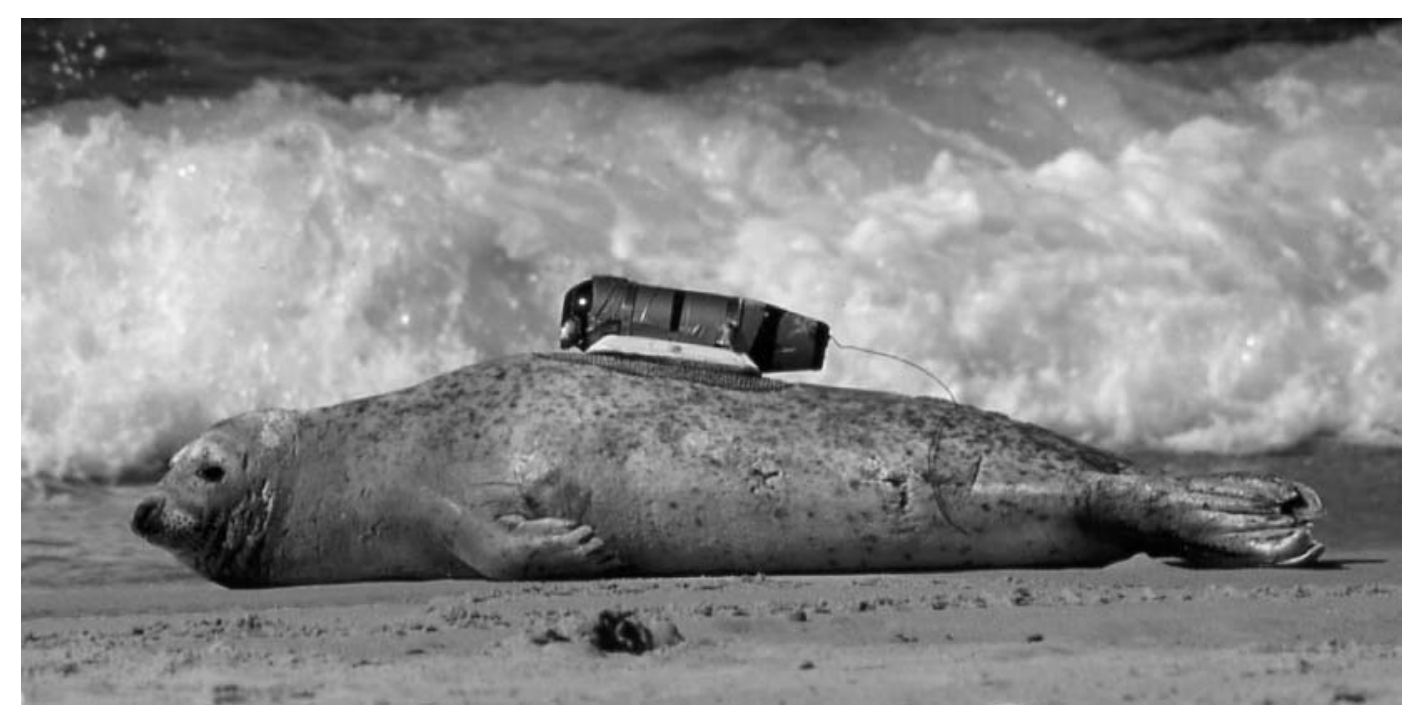

Fig. 1. Phoca vitulina. Crittercam video system used to record foraging behaviour of 39 adult male harbour seals. The tapered cylinder at the rear of the camera is for flotation

mals. The video system and mount were then attached just behind the shoulders of the seal using a combination of nylon mesh and 5 min epoxy (Fig. 1). The instrument was positioned such that the animal's head would usually be visible in the camera's field of view. Deployments were planned to last for $3 \mathrm{~d}$, after which the seal was recaptured. A VHF transmitter placed on the camera housing was used to locate seals for recapture. The camera and mount were removed from the underlying fur by cutting the mesh around the base of the mount. The seal was then weighed and released.

Videotape analysis. A program written in Observer 2.0 software was used to quantify both the frequency and duration of the behaviours recorded on videotape. As the study was conducted during the breeding season, behaviours other than foraging were also recorded. Nonforaging behaviour is dealt with elsewhere.

Foraging behaviour was subdivided into the following components: (1) search-for each dive, the interval from one prey encounter to another; (2) pursuit-the interval from the time of encounter to capture attempt; (3) capture attempt-a rapid thrust of the neck and head in the known direction of prey or into the bottom substrate, but also including crunching or snapping sounds associated with grasping or striking at prey; and (4) handling - the interval from the time of capture to complete ingestion of prey (capture and handling time were recorded together since both components were often too short, $\sim 1 \mathrm{~s}$, to measure accurately).

Prey profitability. In estimating the profitability of ingested prey, handling time was redefined to include the time and energy expended to pursue and handle individual prey (Barkan \& Withiam 1989, referred to here as pursuit/handling [PH]). We did not account for assimilation efficiencies of fish prey, as these are uniformly high (i.e. $>90 \%$ ) in seals (e.g. Lawson et al. 1997). Lengths of observed prey (i.e. sand lance and flounders) were converted to estimates of body mass using regressions in Bowen \& Harrison (1994). Energy content of prey was calculated using prey-specific energy densities $\left(\mathrm{kJ} \mathrm{g}^{-1}\right)$ from Mohn \& Bowen (1996). Prey length was estimated by comparing prey to the known average width of the seal's head. However, both the rapid movement of the seal's head coupled with the speed and orientation of prey with respect to the seal's head meant that accurate estimates were usually not possible.

Capture success was calculated as the percentage of attempts that were successful.

Estimates for each male were then averaged to obtain an overall capture success rate for each prey type. Although capture attempts could be reliably determined, it was not always possible to determine if the attempt had been successful because the seal's head often ( $50 \%$ of the time) extended beyond the field of view when foraging on sand lance. Thus, our estimates of capture success for sand lance may have been underestimated.

Swimming speeds during searching and pursuit of prey were estimated by counting the number of side to side head movements per unit time, a measure of hindflipper stroke rate. The period over which these samples were taken was variable because of the complex nature of the seal's behaviour, but generally 3 or more estimates were made over periods 20 to $30 \mathrm{~s}$ within each VSU. For each male, the mean of these counts for 
each prey type was used as an index of swim speed. To investigate the costs of foraging on different prey, this swim speed index was converted to a swimming speed $\left(\mathrm{m} \mathrm{s}^{-1}\right)$ using a regression of flipper stroke rate against swim speed of an adult harbour seal in captivity (i.e. stroke rate $=32.2$ velocity +29.5 ; Davis et al. 1985). The metabolic cost of pursuit was then calculated using an equation derived from studies on subadult male harbour seals (i.e. $\mathrm{VO}_{2}=6.98 \mathrm{e}^{0.49 \text { speed}}$, where $\mathrm{VO}_{2}$ is in $\mathrm{mlO}_{2} \mathrm{~kg}^{-1} \mathrm{~min}^{-1}$; Williams et al. 1991). This equation, rather than that described by Davis et al. (1985) for adults, was used to calculate metabolic rate because it was based on a wider range of swim speeds ( 0.5 to 3.4 vs 0.0 to $1.4 \mathrm{~m} \mathrm{~s}^{-1}$ ). $\mathrm{VO}_{2}$ estimates were converted to mass-specific energy expenditure $\left(\mathrm{kcal} \mathrm{kg}^{-1}\right.$ $\mathrm{min}^{-1}$ ) using a conversion factor of $4.8 \mathrm{kcal} \mathrm{O}_{2}$ (Williams et al. 1991). The energetic cost of pursuit then was estimated by multiplying the mass-specific rate by the average body mass of each male.

To investigate if foraging behaviour by males was influenced by time of day, time was grouped into 5 periods: (1) $05: 30$ to $07: 30 \mathrm{~h}_{i}(2)$ 07:31 to $09: 30 \mathrm{~h}_{i}$ (3) 09:31 to $11: 30 h_{i}(4) 11: 31$ to $13: 30 h_{i}$ and (5) $>13: 30 h$ based on Eastern Standard Time. Statistical analyses were performed using SPSS Version 10.0. The standard error (SE) of the mean is given as a measure of variability.

\section{RESULTS}

The Crittercam video system was recovered with data 46 times from 39 adult males (Table 1). Two of the males where studied in both 1995 and 1997. For the purpose of this analysis, these repeated deployments were treated as independent samples. In 1996, the video system was put on most males twice within the breeding season. The 2 videotape records of each of these males were combined prior to the analysis.

In 1997, adult males that were equipped with Crittercam were significantly heavier than those in 1996 and 1995 (1-way ANOVA: $F_{2,34}=8.1, \mathrm{p}<0.001$ ). This difference was most likely due to the earlier deployment

Table 1. Phoca vitulina. Number and dates of Crittercam video deployments and mass (sample size in parentheses) of adult male harbour seals studied from 1995 to 1997

\begin{tabular}{|c|c|c|c|c|}
\hline Year & $\begin{array}{l}\text { Number } \\
\text { of seals }\end{array}$ & $\begin{array}{l}\text { Initial body mass }(\mathrm{kg}) \\
\text { mean } \pm \mathrm{SE}\end{array}$ & $\begin{array}{l}\text { Length }(\mathrm{cm}) \\
\text { mean } \pm \mathrm{SE}\end{array}$ & Date \\
\hline 1995 & 8 & $101.6 \pm 2.4(6)$ & $157.8 \pm 2.2(4)$ & 7 Jun-21 Jun \\
\hline $1996^{a}$ & 8 & $102.8 \pm 2.2(8)$ & $156.5 \pm 1.1(8)$ & 2 Jun-22 Jun \\
\hline 1997 & 23 & $112.4 \pm 1.7(23)$ & $159.5 \pm 0.9(23)$ & 19 May-11 Jun \\
\hline Total & 39 & $108.6 \pm 1.4$ & $158.6 \pm 0.7$ & \\
\hline
\end{tabular}

dates in 1997 compared to the other 2 years (Table 1). With these earlier deployments, we hoped to increase the likelihood of recording foraging behaviour. Thus about half of the 1997 deployments occurred prior to 1 June, early in the breeding season when adult males maintain or increase body mass (Walker \& Bowen 1993). Most deployments in 1995 and 1996 were later in the season when males reduce feeding and lose body mass (Coltman et al. 1999). Despite the difference in body mass among years, there was no significant difference in the length of males studied among the 3 years $\left(F_{2,32}=1.7, \mathrm{p}=0.21\right)$. Males wore Crittercam for an average of $3.4 \pm 0.24,3.0 \pm 0.31$, and $4.2 \pm 0.41 \mathrm{~d}$ in 1995, 1996, and 1997, respectively. There was no significant difference among years $\left(F_{2,33}=1.8, \mathrm{p}=0.18\right)$.

Males were weighed at initial capture and again at recovery of the video system to provide evidence of the extent of feeding and to test for instrument effects on male behavior. However, body mass was not taken for all males at recapture, as circumstances did not always permit the animals to be weighed. The average daily change in body mass of males during deployments was $0.3 \pm 0.8 \mathrm{~kg} \mathrm{~d}^{-1}(\mathrm{n}=4),-1.2 \pm 0.4 \mathrm{~kg} \mathrm{~d}^{-1}(\mathrm{n}=8)$, and -0.2 $\pm 0.1 \mathrm{~kg} \mathrm{~d}^{-1}(\mathrm{n}=23)$ in 1995,1996 , and 1997, respectively. Rate of mass change of males did not differ among years (Kruskal-Wallis test: $\mathrm{p}=0.084$ ), however our sample size was quite small in both 1995 and 1996 and thus the comparison had low statistical power.

\section{Description of foraging tactics}

Harbour seal males foraged on at least 5 prey species or taxa. These can be regarded as either cryptic prey, in the case of flounders (American plaice Hippoglossoides platessoides or yellowtail flounder Limanda ferruginea), or conspicuous prey in the case of Atlantic salmon Salmo salar, and gadiod fishes (most likely Atlantic cod Gadus morhua or haddock Melanogrammus aeglefinus). Northern sand lance Ammodytes dubius exhibited both behaviours, being hidden in the sandy bottom and also occurring in large schools. Prey could not be positively identified in a number of the VSUs for 3 reasons: they were too distant from the camera, they were seen too briefly, or low light levels resulted in poor image quality.

\section{Cryptic prey}

Sand lance is a small (maximum length $25 \mathrm{~cm}$ ) bottom-dwelling fish that is often hidden in sandy bottoms to avoid predators. When hidden, sand 
Table 2. Phoca vitulina. Components of foraging behaviour (mean $\pm \mathrm{SE}$ ) of adult male harbour seals and bottom sea temperature and depth where foraging was recorded for cryptic and conspicuous prey types. Prey with same letter do not differ significantly based Tukey multiple comparisons after 1-way ANOVA. VSU: video-sampling unit

\begin{tabular}{|lccc|}
\hline \multirow{2}{*}{ Variable } & \multicolumn{2}{c}{ Cryptic } & \multirow{2}{*}{ Conspicuous } \\
& Sand lance & Flounder & Sand lance \\
\hline Per VSU & & & \\
Search time (min) & $235 \pm 89.3^{\mathrm{a}}$ & $180 \pm 104.1^{\mathrm{a}}$ & $135 \pm 75.9^{\mathrm{b}}$ \\
Capture attempts & $5.5 \pm 1.1^{\mathrm{a}}$ & $1.9 \pm 0.3^{\mathrm{b}}$ & $9.2 \pm 2.0^{\mathrm{c}}$ \\
Capture success (\%) & $63.7 \pm 5.2^{\mathrm{a}}$ & $79.9 \pm 10.6^{\mathrm{a}}$ & $37.5 \pm 6.5^{\mathrm{b}}$ \\
Time spent diving (\%) & $80.9 \pm 1.1^{\mathrm{a}}$ & $81.9 \pm 1.1^{\mathrm{a}}$ & $79.1 \pm 1.0^{\mathrm{a}}$ \\
Depth (m) & $29.9 \pm 2.9^{\mathrm{a}}$ & $34.9 \pm 5.9^{\mathrm{a}}$ & $36.8 \pm 2.2^{\mathrm{a}}$ \\
Bottom temperature $\left({ }^{\circ} \mathrm{C}\right)$ & $7.9 \pm 1.0^{\mathrm{a}}$ & $7.1 \pm 2.1^{\mathrm{a}}$ & $7.7 \pm 1.1^{\mathrm{a}}$ \\
Per event & & & \\
Pursuit duration (s) & $9.3 \pm 1.1^{\mathrm{a}}$ & $7.2 \pm 1.7^{\mathrm{a}}$ & $21.9 \pm 2.4^{\mathrm{b}}$ \\
Capture attempts (s) & $1.0 \pm 0.3^{\mathrm{a}}$ & $2.5 \pm 1.0^{\mathrm{a}}$ & $1.0 \pm 0.2^{\mathrm{a}}$ \\
Handling time (s) & $2.4 \pm 0.5^{\mathrm{a}}$ & $33.0 \pm 8.2^{\mathrm{b}}$ & $1.1 \pm 0.2^{\mathrm{c}}$ \\
Swim speed during pursuit $\left(\mathrm{m} \mathrm{s}^{-1}\right)$ & $2.6 \pm 0.2^{\mathrm{a}}$ & $2.2 \pm 0.3^{\mathrm{a}}$ & $3.4 \pm 0.1^{\mathrm{b}}$ \\
Dive duration (min) & $4.4 \pm 0.2^{\mathrm{a}}$ & $4.3 \pm 0.9^{\mathrm{a}}$ & $4.1 \pm 0.2^{\mathrm{a}}$ \\
No. of seals & 27 & 7 & 17 \\
\hline
\end{tabular}

than returning to the sandy bottom. These types of pursuits always ended in a successful capture.

Flounder was the other cryptic prey type. It was not possible to positively identify the species of flounder, but the 2 most common species near the study site were American plaice and yellowtail flounder. The flounders recorded on videotape were usually (14 of 15 cases) hidden (i.e. we could not see them prior to capture) within the sandy bottom and only became visible after the seal had attempted a capture. We could not determine what cues the seal used to detect flounders. We estimated that the flounders ranged in size from 15 to $30 \mathrm{~cm}$. Of all the prey attacked, handling time was greatest for flounders (Table 2). Males foraged for flounders using a cruising tactic similar to that used while foraging for

lance only became visible on the videotape as a thin flash of silver when individuals darted from one location to another, presumably to avoid capture. Seals quickly captured and handled individual sand lance making it difficult to separately measure the duration of these behaviours. Males used 2 tactics when foraging on cryptic sand lance. The most common tactic, termed 'cruising', was used in about $72 \%$ of the 332 dives in which sand lance was identified. Males swam at medium speed (Table 2) about 1 to $2 \mathrm{~m}$ from the bottom and captured individual fish by quickly thrusting their heads towards the bottom as sand lance appeared or by thrusting their muzzles into the sand and routing for several seconds before encountering the prey. Males usually increased swimming speed with several strokes of the hind flippers just prior to attempting a capture.

The less common tactic, termed 'digging', was used in $28 \%$ of dives and by only 6 of the 27 males that foraged on sand lance. Males descended to the bottom and dug in the sand with one, or occasionally both, front flippers. The effect of this digging was to disturb sand lance hidden in the substrate such that prey surfaced and were briefly visible to the seal. Having seen the prey, the male would strike either by quickly extending its neck, or by darting forward with its entire body while simultaneously extending its neck. Several capture attempts were made before the male moved and began to dig again. It was generally not possible to estimate the distance moved between clusters of capture attempts. In several cases, a male pursued individual sand lance toward the sea surface as the prey, in attempting to escape, swam upward rather cryptic sand lance. In some cases, the male swam at medium speed near the bottom and captured individual flounders as they moved out of the substrate to escape. Pursuit was limited in some cases, but in others it continued in spurts along the bottom as the flounder attempted to camouflage itself by repeatedly entering the sand. In several cases, the flounder was not seen until the male quickly drove his muzzle into the sand and then appeared with the flounder in his mouth. Usually, flounders were consumed whole while the seal swam slowly along the bottom. In 2 of 15 instances, the male released and re-captured the flounder several times before finally consuming the prey. On one occasion, a flounder captured near the end of a dive was taken to the surface where it was consumed.

\section{Conspicuous prey}

Schools of sand lance were approached from behind either while the male swam horizontally near the bottom (93\% of 489 pursuits) or after ascending in the water column and then descending on the school, thereby forcing it toward the bottom. Male harbour seals used 2 tactics when foraging on sand lance schools. In the most common tactic (90\% of pursuits), the male darted toward the edge of the school, apparently attempting to separate a small number of fish from the school or to break the school into smaller units. If successful, these isolated fish immediately swam to the bottom, where they sat motionless or attempted to escape by swimming rapidly near the bottom. In either case, the seal broke off its pursuit of 
the school and pursued isolated individuals. Males made $3.2 \pm 0.4$ capture attempts before re-establishing contact with the school and beginning the process again ( $\mathrm{n}=52$ schools). The other, but less common $(10 \%)$, tactic involved active pursuit and sustained contact with the school during which time it appeared that the seal shifted from one side of the school to the other, attempting to capture single fish along the trailing edge of the school. When pursing non-cryptic prey at high speed, males invariably began to glide with their heads held stationary just prior to striking downwards at individual prey.

\section{Underwater regurgitation of meals}

Eight males regurgitated meals while diving. Seven of these males had apparently consumed only sand lance, whereas the other male had consumed 1 or more flounders and sand lance. The degree of digestion of regurgitated sand lance varied from prey consisting of different size pieces, in 5 cases, to mostly whole prey, in 3 cases. The 1 regurgitated flounder also showed little evidence of digestion. Relatively undigested prey (both flounder and sand lance) were re-consumed, whereas more heavily digested sand lance was ignored. One male regurgitated the same meal of sand lance twice within a $10 \mathrm{~min}$ VSU, and both times apparently re-consumed the entire meal. The minimum number of whole prey regurgitated in the 3 cases mentioned above was 16, 44 and 82 sand lance ranging in estimated length from 13 to $20 \mathrm{~cm}$ ( $\mathrm{n}=25$ prey measured from all 3 meals combined).

\section{Quantitative analysis of foraging behaviour}

Foraging was observed in $31.9 \%$ of 113 VSUs, $48.6 \%$ of 222 VSUs, and $40.0 \%$ of 452 VSUs recorded in 1995 , 1996, and 1997, respectively. Cryptic ( $\mathrm{n}=115$ VSUs) and conspicuous sand lance $(\mathrm{n}=88)$ were recorded most frequently, followed by flounders $(n=15)$. Gadoid fishes were seen 4 times and salmon only once. Prey were identified to species or taxa in $68.6 \%$ of VSUs in which prey were recorded.

Foraging was recorded for 37 of the 39 males studied. Of these, 29 males foraged on sand lance, 7 on flounders, and 4 on gadoid species. Thirty of the 37 males foraged on prey that could be identified. Fifteen males $(50 \%)$ fed on both cryptic and conspicuous prey, $13(43.3 \%)$ fed on only cryptic prey and 2 (6.7\%) fed on conspicuous prey only.

Sample sizes for the components of foraging behavior varied such that it was not possible to conduct a single analysis of all components. Thus, the effect of prey characteristics on each foraging component was examined using a 1-way General Linear Model (GLM). Only the 3 most commonly recorded prey types (i.e. cryptic and conspicuous sand lance, and flounders) were used in these analyses. Thirty-seven males spent an average of $2.8 \pm 0.2 \mathrm{~min}$ searching per VSU after having encountered prey at an average estimated swimming speed of $1.9 \pm 0.1 \mathrm{~m} \mathrm{~s}^{-1}$. Although males could have encountered any prey type during searching, within each VSU they foraged on only 1 type of prey in all but a handful of cases. If we assume that males were searching for the prey type observed within each VSU, then search time was prey-dependent $\left(F_{2,37}=5.3, \mathrm{p}=0.009\right.$; Table 2$)$. Males spent more time searching for cryptic sand lance than for conspicuous schooling sand lance (Tukey multiple comparisons: $\mathrm{p}=$ 0.007), but search time for flounders and either cryptic or conspicuous sand lance did not differ significantly (Tukey multiple comparisons: $\mathrm{p}=0.32$ and 0.53 , respectively). Other components of foraging behavior also differed among prey types or, in the case of sand lance, with prey behavior. Time spent in detection and pursuit of prey was significantly less when foraging on cryptic sand lance and flounders compared to conspicuous sand lance $\left(\log _{\mathrm{e}}\right.$-transformed data: $F_{2,48}=$ 21.5, $\mathrm{p}<0.001)$. Swim speed during pursuit also differed among prey types $\left(F_{2,46}=5.5, \mathrm{p}=0.007\right)$. Males swam about $25 \%$ faster when foraging on conspicuous sand lance as they did when foraging on cryptic sand lance or flounders (Tukey multiple comparisons: $\mathrm{p}<$ 0.02). Handling time per prey also differed among prey species $\left(\log _{\mathrm{e}}\right.$-transformed data: $\left.F_{2,37}=17.5, \mathrm{p}<0.001\right)$, with about 14 to 30 times greater time spent handling flounders compared to either cryptic or conspicuous sand lance (Tukey multiple comparisons: $p$ < 0.001). Capture success differed significantly among prey types (Kruskal-Wallis: $\chi^{2}=10.7$, df $=2, p=0.005$ ). There was no significant difference in the percentage of time spent diving among these prey types (arcsinetransformed data: $F_{2,48}=1.1, \mathrm{p}=0.34$; Table 2).

Neither water depth $\left(F_{2,42}=1.5, \mathrm{p}=0.24\right)$ nor sea temperature at the bottom of dives (Kruskal Wallis: $\chi^{2}=0.64$, df $=2, p=0.72$ ) differed among prey types. The frequency of foraging on cryptic and conspicuous prey also did not differ by time of day (Likelihood ratio $=5.3$, df $=3, p=0.15$ ). Dive duration over all behaviours averaged $4.0 \pm 0.12 \mathrm{~min}$. Dive duration did not differ among prey types $\left(F_{2,48}=0.74, \mathrm{p}=0.48\right.$; Table 2$)$.

\section{Foraging energetics}

Pursuit/handling (PH) time and the energetic cost of PH per prey differed significantly among prey types (Table 3). Males spent significantly less time handling 
Table 3. Phoca vitulina. Pursuit/handling time per prey and associated mass-specific energetic costs. Prey with same letter do not differ significantly based Tukey multiple comparisons after 1-way ANOVA

\begin{tabular}{|lcrrrr|}
\hline & \multicolumn{2}{c}{ Cryptic } & Conspicuous & $F_{2,36}$ \\
& Sand lance & Flounder & Sand lance & \\
\hline Pursuit/handling per prey $(\mathrm{s})^{*}$ & $11.8 \pm 1.5^{\mathrm{a}}$ & $39.6 \pm 9.8^{\mathrm{b}}$ & $23.7 \pm 3.6^{\mathrm{b}}$ & 10.6 & $<0.001$ \\
Pursuit/handling cost per prey $\left(\mathrm{kJ} \mathrm{min}{ }^{-1}\right)$ & $14.8 \pm 2.7^{\mathrm{a}}$ & $30.3 \pm 7.9^{\mathrm{ab}}$ & $32.1 \pm 4.9^{\mathrm{b}}$ & 5.5 & 0.008 \\
${ }^{*} \log _{10}$-transformed & & & & \\
& & & \\
\hline
\end{tabular}

Table 4. Mass and energy content of each prey type at 4 selected lengths. Mass is taken from Bowen \& Harrison (1994); energy per prey assumes an energy density of $6.7 \mathrm{~kJ} \mathrm{~g}^{-1}$ in sand lance and $4.3 \mathrm{~kJ} \mathrm{~g}^{-1}$ in plaice (from Mohn \& Bowen 1996)

\begin{tabular}{|lccc|}
\hline Prey & $\begin{array}{c}\text { Length } \\
(\mathrm{cm})\end{array}$ & $\begin{array}{c}\text { Mass } \\
(\mathrm{g})\end{array}$ & $\begin{array}{c}\text { Energy per prey } \\
(\mathrm{kJ})\end{array}$ \\
\hline Sand lance & 10 & 8 & 53.6 \\
& 15 & 14.3 & 95.8 \\
& 20 & 23.6 & 158.1 \\
Flounder & 25 & 34.9 & 233.8 \\
(American plaice) & 10 & 5.2 & 22.6 \\
& 15 & 20.6 & 88.6 \\
& 20 & 54.1 & 232.6 \\
& 25 & 114.5 & 492.3 \\
\hline
\end{tabular}

cryptic sand lance than either flounders or conspicuous sand lance (Tukey multiple comparisons: $\mathrm{p}=0.001$ and 0.007, respectively). PH cost of cryptic sand lance was significantly less than that of conspicuous sand lance (Tukey multiple comparisons: $p=0.013$ ), but not flounder (Tukey multiple comparisons: $\mathrm{p}=0.095$ ). $\mathrm{PH}$ cost did not differ significantly between flounder and conspicuous sand lance (Tukey multiple comparisons: $\mathrm{p}=0.993)$.

The body length of relatively few prey could be estimated precisely. Estimates ranged from 10 to $23 \mathrm{~cm}$ for sand lance and from 15 to $30 \mathrm{~cm}$ for flounders. Given the few estimates and the likely error associated with individual measurements, prey energy content for

Table 5. Phoca vitulina. Mean $( \pm \mathrm{SE})$ gross energy intake $\left(\mathrm{kJ} \mathrm{min}{ }^{-1}\right.$ ) as a function of prey body length. For a given size, prey with same letter do not differ significantly in gross energy, prey with different letters differ significantly, $\mathrm{p}<0.05$, based Tukey multiple comparisons after 1-way GLM

\begin{tabular}{|lccc|}
\hline $\begin{array}{l}\text { Prey length } \\
(\mathrm{cm})\end{array}$ & \multicolumn{2}{c|}{ Cryptic prey } & $\begin{array}{c}\text { Conspicuous prey } \\
\text { Sand lance }\end{array}$ \\
\hline 10 & $38 \pm 4^{\mathrm{a}}$ & $11 \pm 2^{\mathrm{b}}$ & $33 \pm 6^{\mathrm{a}}$ \\
15 & $67 \pm 8^{\mathrm{a}}$ & $43 \pm 6^{\mathrm{a}}$ & $59 \pm 10^{\mathrm{a}}$ \\
20 & $111 \pm 12^{\mathrm{a}}$ & $112 \pm 16^{\mathrm{a}}$ & $98 \pm 17^{\mathrm{a}}$ \\
25 & $164 \pm 18^{\mathrm{a}}$ & $237 \pm 34^{\mathrm{a}}$ & $144 \pm 26^{\mathrm{a}}$ \\
\hline
\end{tabular}

sand lance and flounders were calculated at 4 body lengths (Table 4). Estimated rates of gross energy intake increased rapidly with prey length for both sand lance and flounder (Table 5). The lower rates of gross energy intake for males foraging on conspicuous sand lance arose from the lower capture success associated with conspicuous compared to cryptic sand lance. With the exception of $10 \mathrm{~cm}$ flounder, estimated gross energy intake for a given size did not differ among prey types (Table 5).

Estimated profitability increased with increasing prey size (Fig. 2). The profitability of cryptic sand lance and flounders did not differ significantly (Tukey multiple comparisons: $p>0.3$ for all prey lengths), but cryptic sand lance was more profitable than conspicuous sand lance at all prey sizes (Tukey multiple comparisons: $\mathrm{p}<$ 0.03 for all prey lengths). Flounders and conspicuous sand lance did not differ in profitability (Tukey multiple comparisons: $\mathrm{p}>0.15$ for prey 10 to $20 \mathrm{~cm}$ in length) except for the largest size-class of flounders which were more profitable than the largest size-class of conspicuous sand lance (Tukey multiple comparisons: $p=0.03$, Fig. 2). Small flounders and conspicuous sand lance $<20 \mathrm{~cm}$ in body length were unprofitable at the estimated percent capture success (Fig. 2).

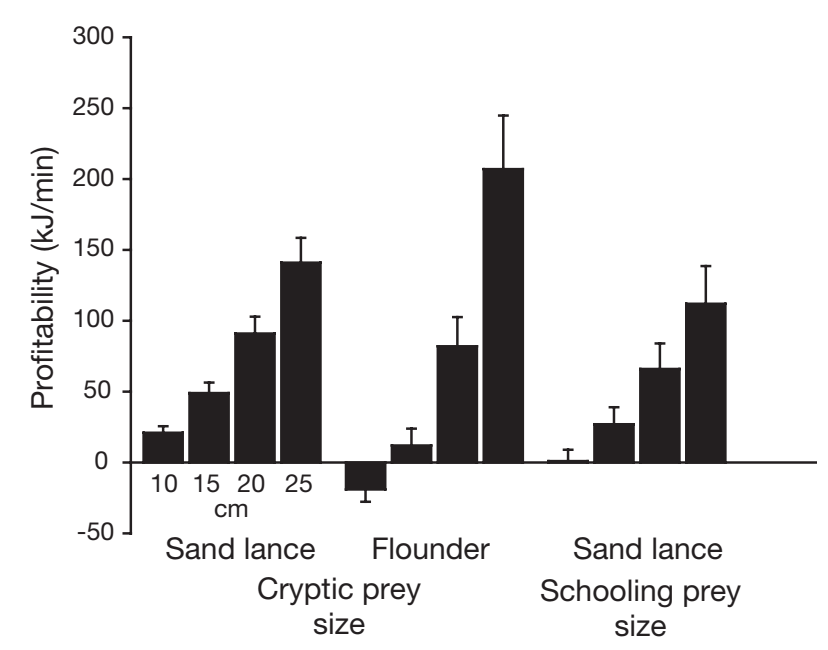

Fig. 2. Estimates of profitability $\left(\mathrm{kJ} \mathrm{min}{ }^{-1}\right.$; mean $\left.\pm \mathrm{SE}\right)$ of cryptic and conspicuous prey as a function of prey body length 


\section{DISCUSSION}

Animal-borne video has been recently used to investigate the foraging ecology and habitat use of several species of pinnipeds, penguins and sharks (Davis et al. 1999, Parrish et al. 2000, Ponganis et al. 2000, Heithaus et al. 2001). However, this is the first study to record a large number of captures of different types of prey, thus permitting an analysis of foraging tactics and preliminary estimates of prey profitability. Harbour males foraged on prey exhibiting considerable contrasts in both behaviour and body form. Our findings indicate that harbour seal males used different tactics for different prey and that these tactics had energetic consequences that likely affected the profitability of prey. Furthermore, differences in behaviour within prey species had significant effects on predator tactics.

\section{Instrument effects}

Instrument effects have been reported for various species, including pinnipeds (e.g. Wilson et al. 1986, Croll et al. 1991, Walker \& Boveng 1995, Boyd et al. 1997). Walker \& Boveng (1995) found that Antarctic fur seals Arctocephalus gazella equipped with a TDR and VHF radio transmitter had longer foraging trips than in controls, which carried only a radio transmitter. Boyd et al. (1997) found that female Antarctic fur seals, fitted with additional drag in the form of a block of wood weighing about $0.6 \%$ of body mass, also had longer foraging trips than when controls were used, but mass change over the foraging trip did not differ between groups. The video system we used is relatively large (1.8\% of mean body mass), and thus it is important to assess to what extent carrying the system may have affected foraging behaviour. Most adult male harbour seals on Sable Island lose body mass during the breeding season, and the rate of mass loss increases in the latter portion of the season (Walker \& Bowen 1993). The rate of mass loss of males carrying Crittercam was significantly less $\left(-0.4 \pm 0.16 \mathrm{~kg} \mathrm{~d}^{-1}, t=3.1, \mathrm{df}=34, \mathrm{p}=\right.$ $0.004)$ than that reported for males, during the breeding season, that did not carry instruments $\left(-0.9 \mathrm{~kg} \mathrm{~d}^{-1}\right.$; Walker \& Bowen 1993, their Fig. 2). Further, the average duration of dives by males wearing the Crittercam $(4.0 \pm 0.12 \min , \mathrm{n}=37)$ was not significantly different than for males fitted with TDRs and VHF transmitters (combined mass $<0.5 \%$ body mass, $3.8 \pm 0.13 \mathrm{~min}, \mathrm{n}=$ 31; Coltman et al. 1997). We acknowledge that more meaningful comparisons would have been with control males from the same years. However, this was not feasible. It is also possible that males carrying the Crittercam spent more time at sea, but we do not have comparable data over short periods of time to make this comparison. Thus, although carrying the Crittercam presumably affected the behaviour of males, our data suggest that the effects were minor over the few days that each male carried the video system.

\section{Foraging behavior}

The objective of our study was not to estimate the diet of male harbour seals. Based on the videotape recordings, harbour seal males foraged most often on sand lance, but flounders and several other fishes were also consumed. However, it is likely that other prey were also eaten given that each seal carried the video system for only $3 \mathrm{~d}$ and over that period only $3 \mathrm{~h}$ of behaviour were sampled. Furthermore, prey type was not identified in about $30 \%$ of VSUs. In 1997 a blubber biopsy was taken from all animals that carried the video system to provide an estimate of the additional prey species that males consumed prior to our study. Based on a comparison of the fatty acid signatures of these blubber samples with the fatty acid profiles of potential prey species, the diet of the study males was estimated to comprise an average of $62 \%$ sand lance, $14 \%$ flounders, 9\% capelin Mallotus villosus, 5\% Atlantic cod, 4\% Atlantic herring Clupea harengus, and $3 \%$ shrimp Pandalus borealis (S. J. Iverson et al. unpubl. data). Thus, the prey species most commonly recorded during our study were apparently also among the most frequent prey in the diet of these males prior to wearing the video system. This lends additional evidence that carrying the camera may have had only minor effects on the foraging behaviour of our study males.

Predators use a number of tactics to capture prey, and these can be broadly classified as sit-and-wait (also known as ambush) and active searching (Stander \& Albon 1993, Wells et al. 1999). Sit-and-wait tactics are used in situations where prey are mobile and thus encounter rate with a stationary and often concealed predator is high enough for this to be economical (e.g. dark chub Zacco temmincki; Katano 1996). Our findings reveal how harbour seal foraging tactics change in relation to some prey characteristics, however, we did not set out to test predictions of optimal foraging models as we were unable to determine both the distribution and abundance of potential prey or prey patches. Nevertheless, some optimality models of foraging behaviour of diving predators predict that net rate of energy gain and foraging efficiency should be maximized if seals remain stationary when hunting active prey and if seals swim at the minimum cost of transport (MCT) velocity when hunting sedentary prey (Thompson et al. 1993). However, we did not observe a sit-and-wait tactic when harbour seals were hunting 
active prey. Rather, our findings show that harbour seal males used several different active search tactics to capture active prey. Harbour seal males appeared to swim near the MCT velocity when hunting relatively sedentary prey such as cryptic sand lance and flounder. Similarly, Thompson and colleagues (cited in Thompson et al. 1993) found that harbour seals actively hunted for cryptic stationary flat fish (pleuronectid species) at near the MCT velocity.

We may not have recorded the full range of foraging tactics used by harbour seals for several reasons. First, we recorded foraging on only a few of the many prey species know to occur in the diet (Bowen \& Harrison 1994, authors' unpubl. data). Second, our study was conducted during the breeding season when the composition of the diet and the corresponding range of foraging tactics used by males may be constrained by reproductive behaviour (Coltman et al. 1997). Third, seasonal differences in prey types or in prey behaviour might lead to different foraging tactics. Finally, we recorded behaviour only during the day and different tactics might be used during darkness when the relative importance of the predator's sensory systems presumably differ.

The different foraging tactics used by harbour seal males apparently reflected differences in the behavior and size of prey. PH times (Table 3) were shortest for cryptic sand lance, intermediate for schooling sand lance and the longest for flounders. Most of the $\mathrm{PH}$ time for flounders was associated with consuming this prey type, whereas pursuit of prey was the dominant component of handling time for sand lance. Our results also show that tactics may differ within species according to variation in prey behavior. Harbour seal males used repeated, high-speed pursuit of schools and then of individual prey that were separated from the school when foraging on conspicuous sand lance, but used a slower cruising or a digging tactic when foraging on cryptic sand lance. Although we do not have quantitative estimates of sand lance densities where males foraged, our impression was that digging was used in areas of high prey density, where disturbance of the bottom would be more likely to expose prey within striking distance of the predator. On the other hand, cruising may be used in areas of lower prey density, as this tactic likely results in a greater area searched than digging.

The regurgitation and immediate re-consumption of prey was unexpected. We are uncertain why this might occur, but it seems common. We speculate that the males may ingest sand and seawater while foraging on cryptic prey such as sand lance and that regurgitation is a means of eliminating these substances. To the extent that regurgitation is both common and specific to certain prey types, there is an implication for the estimation of diets based on the recovery of prey hardparts from stomach contents or faeces. Namely, this could be another source of bias by differentially eliminating the structures of some prey species used in prey identification.

\section{Foraging energetics}

To estimate swimming speed, we used a relationship between hind-flipper stroke frequency and velocity for an adult harbour seal, which required extrapolation to 150 beats $\mathrm{min}^{-1}$, well above the measured 70 beats $\mathrm{min}^{-1}$ by Davis et al. (1985). However, the relationship between velocity and stroke frequency for a yearling harbour seal rose linearly to over 100 beats $\mathrm{min}^{-1}$ (Davis et al. 1985). Nevertheless, our extrapolation presumes a linear relationship over this greater range which might not be valid. Estimates of gross energy intake are sensitive to the size and energy content of prey and capture success. Although we could only estimate the length of relatively few prey eaten by male harbour seals, estimates of gross energy intake per prey at the 4 prey lengths cover the size range of prey observed in this study, and thus, should provide a reasonable basis for drawing preliminary conclusions. Prey body mass and energy densities were estimated from fish collected near the study area, which over the range of sizes used in our calculations showed little evidence of increased energy density with length (S. J. Iverson \& W. D. Bowen unpubl. data). We likely have underestimated the capture success of sand lance. The head of some males often extended beyond the field of view of the camera while they were attempting to capture prey such that we could not be certain of the outcome. We attempted to reduce this bias by eliminating, from the estimation of capture success, data of individual males if a large fraction of the time we could not be certain of the outcome of an attempt.

Our results indicate that harbour seal prey differ in profitability. However, the profitability of given prey types may not be constant. Profitability has been shown to vary with prey size within species in several species of fish (Wanzenböck 1995, Scharf et al. 1998). Pinnipeds appear to forage both during daylight and darkness (Kooyman 1975, Boness et al. 1994, Coltman et al. 1997, Le Boeuf et al. 2000), thus it will be important to determine how light level and the sensory systems used to locate prey could affect profitability.

Profitability is only 1 factor affecting foraging decisions of predators. Taking the most profitable prey does not necessarily maximize the long-term average rate of energy intake because it ignores the search time between encounters (Engen \& Stenseth 1984, Stephens et al. 1986). Encounter rates may also play an 
important role in determining which foods are eaten (Pyke et al. 1977, Engen \& Stenseth 1984). If we assume that males were searching for specific prey, then our data suggest that harbour seal males spent more time searching for cryptic sand lance than they did for schooling sand lance. Thus, accounting for differences in search time might change prey profitability. However, our estimates of search time were based on short-term (10 $\mathrm{min})$ samples of behaviour and therefore may not be representative of search time and encounter rates over longer periods. Although search time is predicted to influence prey choice in simultaneous-encounter models, Barkan \& Withiam (1989) found that chickadees Parus atricapillus preferred the more profitable prey regardless of search time, indicating that the birds were not maximizing long-term rate of energy intake contrary to the common assumption of optimality models. Although we have much to learn about the currency used by pinnipeds, it seems likely that the profitability of prey may also play an important role in prey choice.

Acknowledgements. We thank Carrie Beck, Sara Iverson and Jim McMillan for assistance with the fieldwork. Carrie Beck, Debbie Austin and 3 anonymous reviewers provided valuable comments on a previous draft of the manuscript. Funding for the research was provided by the Natural Science and Engineering Research Council of Canada, The National Geographic Society, and the Smithsonian Abbott and Nelson Restricted Endowment Funds and the Friends of the National Zoo.

\section{LITERATURE CITED}

Barkan CPL, Withiam ML (1989) Profitability, rate maximization, and reward delay: a test of the simultaneousencounter model of prey choice with Parus atricapillus. Am Nat 134:254-272

Boness DJ, Bowen WD, Oftedal OT (1994) Evidence of a maternal foraging cycle resembling that of otariid seals in a small phocid, the harbor seal. Behav Ecol Sociobiol 34: 95-104

Boveng PL, Hiruki LM, Schwartz MK, Bengtson JL (1998) Population growth of Antarctic fur seals: limitation by a top predator, the leopard seal? Ecology 79:2863-2877

Bowen WD (1997) Role of marine mammals in aquatic ecosystems. Mar Ecol Prog Ser 158:267-274

Bowen WD, Harrison GD (1994) Offshore diet of grey seals Halichoerus grypus near Sable Island, Canada. Mar Ecol Prog Ser 112:1-11

Bowen WD, Siniff DB (1999) Distribution, population biology, and feeding ecology of marine mammals. In: Reynolds JEI, Rommel SA (eds) Biology of marine mammals. Smithsonian Press, Washington, DC, p 423-484

Boyd IL (1996) Temporal scales of foraging in a marine predator. Ecology 77:426-434

Boyd IL, McCaffery DJ, Walker TR (1997) Variation in foraging effort by lactating Antarctic fur seals: response to simulated foraging costs. Behav Ecol Sociobiol 40:135-144

Coltman DW, Bowen WD, Boness DJ, Iverson SJ (1997) Bal- ancing foraging and reproduction in male harbour seals: an aquatically mating pinniped. Anim Behav 54:663-678

Coltman DW, Bowen WD, Wright JM (1999) A multivariate analysis of phenotype and paternity in male harbor seals, Phoca vitulina, at Sable Island, Nova Scotia. Behav Ecol 10:169-177

Croll DA, Osmek SD, Bengtson JL (1991) An effect of instrument attachment on foraging trip duration in chinstrap penguins. Condor 93:777-779

Croxall JP, Everson I, Kooyman GL, Ricketts C, Davis RW (1985) Fur seal diving behaviour in relation to vertical distribution of krill. J Anim Ecol 54:1-8

Davis RW, Williams TM, Kooyman GL (1985) Swimming metabolism of yearling and adult harbour seals Phoca vitulina. Physiol Zool 58:590-596

Davis RW, Fuiman LA, Williams TM, Collier SO, Hagey WP, Kanatous SB, Kohin S, Horning M (1999) Hunting behavior of a marine mammal beneath the Antarctic fast ice. Science 283:993-996

Diaz JA, Carrascal LM (1993) Variation in the effect of profitability on prey size selection by the lacertid lizard Psammadromus algirus. Oecologia 94:23-29

Emlen JM (1966) The role of time and energy in food preference. Ecology 47:611-617

Engen S, Stenseth NC (1984) A general version of optimal foraging theory: the effect of simultaneous encounters. Theor Pop Biol 26:192-204

Hart PJB (1997) Foraging tactics. In: Godin JGJ (ed) Behavioural ecology of teleost fishes. Oxford University Press, Oxford, p 104-161

Heithaus MR, Marshall GJ, Buhleier BM, Dill LM (2001) Employing Crittercam to study habitat use and behavior of large sharks. Mar Ecol Prog Ser 209:307-310

Houston AI, Carbonne C (1992) The optimal allocation of time during a dive cycle. Behav Ecol 3:255-265

Katano O (1996) Foraging tactics and home range of dark chub in a Japanese river. Oecologia 106:199-205

King JE (1983) Seals of the World. Comstock Publishing Associates, Ithaca, NY

Kooyman GL (1975) A comparison between day and night diving in the Weddell seal. J Mamm 56:563-574

Kramer DL (1988) The behavioural ecology of air breathing by aquatic animals. Can J Zool 66:89-94

Kruuk H (1993) The diving behaviour of the platypus (Ornithorhynchus anatinus) in waters with different trophic status. J Appl Ecol 30:592-598

Kvitek RG, Bowlby CE, Staedler M (1993) Diet and foraging behavior of sea otters in Southeast Alaska. Mar Mamm Sci 9:168-181

Lawson JW, Miller EH, Noseworthy E (1997) Variation in assimilation efficiency and digestive efficiency of captive harp seals (Phoca groenlandica) on different diets. Can J Zool 75:1285-1291

Le Boeuf BJ, Crocker DE, Costa DP, Blackwell SB, Webb PM, Houser DS (2000) Foraging ecology of northern elephant seals. Ecol Monogr 70:353-382

Marshall GJ (1998) Crittercam: an animal-borne imaging and data logging system. Mar Tech Soc J 32:11-17

McLaren IA (1993) Growth in pinnipeds. Biol Rev 68:1-79

Merrick RL, Loughlin TR (1997) Foraging behavior of adult females and young-of-year Steller sea lions (Eumetopias jubatus) in Alaskan waters. Can J Zool 75:776-786

Mohn R, Bowen WD (1996) Grey seal predation on the eastern Scotian Shelf: modelling the impact on Atlantic cod. Can J Fish Aquat Sci 53:2722-2738

Parrish FA, Craig MP, Ragen TJ, Marshall GJ, Buhleier BM (2000) Identifying diurnal foraging habitat of endangered 
Hawaiian monk seals using a seal-mounted video camera. Mar Mamm Sci 16:392-412

Pierce GJ, Boyle PR (1991) A review of methods for diet analysis in piscivorous marine mammals. Oceanogr Mar Biol 29:409-486

Ponganis PJ, Van Dam RP, Marshall G, Knower T, Levenson DH (2000) Sub-ice foraging behavior of emperor penguins. J Exp Biol 203:3275-3278

Pulliam HR (1974) On the theory of optimal diets. Am Nat 108: 59-75

Pyke GH, Pulliam HR, Charnov EL (1977) Optimal foraging: a selective review of theory and tests. Quart Rev Biol 52: $137-154$

Ropert-Coudert Y, Kato A, Bost CA, Rodary D, Sato K, Le Maho Y, Naito Y (2002) Do Adelie penguins modify their foraging behaviour in pursuit of different prey? Mar Biol 140:647-652

Schaller GB (1972) The Serengeti lion: a study of predatorprey relations. Chicago University Press, Chicago

Scharf FS, Buckel JA, Juanes F, Conover DO (1998) Predation by juvenile piscivorous bluefish (Pomatomus saltatrix): the influence of prey to predator size ratio and prey type on predator capture success and prey profitability. Can J Fish Aquat Sci 55:1695-1703

Scheel D (1993) Profitability, encounter rates, and prey choice of African lions. Behav Ecol 4:90-97

Schoener TW (1971) Theory of feeding strategies. Ann Rev Ecol Syst 2:369-404

Somers MJ (2000) Foraging behaviour of Cape clawless otters (Aonyx capensis) in a marine habitat. J Zool 252:473-480

Stander PE, Albon SD (1993) Hunting success of lions in a semi-arid environment. Symp Zool Soc Lond 65:127-143

Editorial responsibility: Otto Kinne (Editor),

Oldendorf/Luhe, Germany
Stephens DW, Krebs JR (1986) Foraging theory. Princeton University Press, Princeton, NJ

Stephens DW, Lynch JF, Sorensen AE, Gordon C (1986) Preference and profitability: theory and experiment. Am Nat 127:533-553

Sunquist ME, Sunquist FC (1989) Ecological constraints on predation by large felids. In: Gittleman JL (ed) Carnivore behavior, ecology, and evolution. Cornell University Press, Ithaca, NY, p 283-301

Thompson D, Hiby AR, Fedak MA (1993) How fast should I swim? Behavioural implications of diving physiology. Symp Zool Soc Lond 66:349-368

Walker BG, Boveng PL (1995) Effects of time-depth recorders on maternal foraging and attendance behaviour in Antarctic fur seals (Arctocephalus gazella). Can J Zool 73: 1538-1544

Walker BG, Bowen WD (1993) Changes in body mass and feeding behaviour in male harbour seals, Phoca vitulina, in relation to female reproductive status. J Zool 231: 423-436

Wanzenböck J (1995) Changing handling times during feeding and consequences for prey size selection of $0+$ zooplanktivorous fish. Oecologia 104:372-378

Wells RS, Boness DJ, Rathbun GB (1999) Behavior. In: Reynolds JEI, Rommel SA (ed) Biology of marine mammals. Smithsonian Press, Washington, DC, p 324-422

Williams TM, Kooyman GL, Croll DA (1991) The effect of submergence on heart rate and oxygen stores of swimming seals and sea lions. J Comp Physiol B 160:637-644

Wilson RP, Grant WS, Duffy DC (1986) Recording devices on free-ranging marine animals: does measurement affect foraging performance. Ecology 67:1091-1093

Submitted: January 22, 2002; Accepted: August 21, 2002

Proofs received from author(s): November 11, 2002 